\title{
Learning Pronunciation with OERs: a practical case for Medicine students
}

\author{
Bellés-Fortuño, Begoña ${ }^{a}$; Bellés-Calvera, Lucía ${ }^{a}$
}

${ }^{\mathrm{a}}$ English Studies Department, Universitat Jaume I, Spain

\begin{abstract}
The aim of this study is to improve English pronunciation in the university classroom of first-year Medicine students through the use of OERs. Technologies such as Voki or LEO network are used in the practical sessions of the English for Health Sciences module. Voki platform allows learners to practise and improve their fluency and spoken skills in the target language. LEO network was also used to allow students to exercise and check their pronunciation performance with the tool 'Learn English through dictation'. Two surveys addressed to students tried to delve into their level of English pronunciation and the importance given to this ability up to now. We aimed at knowing how much the students were exposed to pronunciation training before entering university and whether this training was presented through the use of new technologies. First-year Medicine students seemed motivated to the improvement and learning of pronunciation techniques through the use of OERs. A final questionnaire revealed that, although the teaching proposal with the use of computer tools was rewarding, not all of them seemed so fond of new technologies as expected.
\end{abstract}

Keywords: EFL; Medicine students; teaching pronunciation; OERs. 


\section{Introduction}

In recent years, several studies have acknowledged the immense potential of OERs for teaching and learning due to the generation of new abilities in the classroom related to forms of communication or collaboration (Conole \& Alevizou, 2010). Regarding the teaching and learning of languages, it has been claimed that OERs are able to reduce the time needed to prepare classes (Wenk, 2010) as well as to reduce teachers' isolation by using dialogic and more learner-centred approaches (Mayes \& Freitas, 2004).

Higher Education Institutions have been urged to widening the use and creation of OERs. In the last decade OERs have gained place in universities due to the European policies published after the Bologna Declaration. OERs have been attributed many beneficial learning and teaching skills for the university classroom, since their free and easy access have undoubtedly the potential of becoming universal and available to the whole learning and teaching community. However, some authors have noted the risks of OERs as regards social exclusion. Those not fond of new technologies or not connected could be left behind and excluded from the classroom community.

The current paper presents the results obtained after introducing the use of some specific OERs for the learning of English Pronunciation to a group of first-year Medicine students enrolled in their English for Health Sciences module. The participants had never used the OERs introduced in the classroom before. Although a very positive response was hypothesized, the answers from a survey measuring students' satisfaction with the sessions revealed that not all the students were prone to use OERs in their Pronunciation module. Several activities were designed to be fulfilled with the use of some OERs which, although no specifically designed for language teaching and learning, have proven to be useful for that goal.

\section{The Medicine classroom}

The classroom setting under which the study takes place is that of a first year degree in Medicine, a total number of 63 students were exposed to OERs to improve English pronunciation in the English for Health Sciences module. For these students English is taught as a foreign language and the four skills are practised in class, i.e. reading, writing, listening and speaking. They are exposed to medical texts; both written and spoken, terminology is specific to the field. A high percentage of the total subject grade is devoted to the spoken understanding and production (5.5 out of 10), so pronunciation becomes an important asset in the oral tests, these include: group presentation on a medical topic or a dialogue in a consultation between doctor and patient or patient and nurse. 


\subsection{The surveys}

Two different surveys were created and passed on the Medicine students to be filled in before and after the session. The first initial questionnaire included questions regarding personal data such as gender and year of birth. It is important to mention at this point that both surveys were completely anonymous. Some other aspects of the questionnaire gathered information about their proficient use of OERs and other technologies or their level of English.

The final survey aimed at gathering information about their satisfaction with the session and the usefulness of the OERs presented and used. In this final survey they had to number in a 5-point likert items such as: a) Using OERs to fulfil the activities has increased my motivation to communicate in English, or b) The activities done using OERs are not attractive and dynamic (see Appendix for details).

\section{The activities}

The activities designed included exercises to be fulfilled with the OERs that had been previously explained. The first activity, aimed at practising vowel and consonant sounds in isolation, required the use of the dictation tool and the text-to-speech option. Afterwards, students had to check the pronunciation of the words listed and then record themselves using Voki.

The second activity was desgined to practise the pronunciation of words that may be tricky for students. To complete it, learners were provided with the tongue twitster that goes as follows: If two witches watched two watches, which witch would watch which watch? Then, they were again asked to record themselves on Voki. For reasons of space the activities cannot be included in the paper.

Next section presents some of the pronunciation improvements and mistakes made by the participants in the study while using the OERs proposed.

\section{Results and discussion}

As regards the activities designed to implement the use of OERs in the Medicine classroom, the results of the activities concerning vowels and consonants as well as minimal pairs are now provided. 


\subsection{Vowels and Consonants}

Results from the vowels and consonants activity are quite striking. Figure 1 below illustrates the number of words with silent consonants that were mispronounced by Medicine students. In fact, despite having the opportunity to practise and hear the words as many times as they considered necessary before recording them, it can be clearly seen that nearly $25 \%$ of the participants had serious difficulties in identifying words with silent letters.

The figure below shows that the most salient mispronunciations correspond to bomb, receipt and doubt. Around 20 students pronounced bomb as /bpmb/, receipt as /re'si:pt /, and doubt as /davbt/ or /dabt/. These pronunciation errors are closely followed by hymn and numb. The phoneme /h/ in hymn is replaced either by a sound similar to the Scottish 'ch' (Coe, 1987) or by pronouncing the $/ \mathrm{n} /$, thereby resulting in /hImn/. On the other hand, numb tends to be recorded as $/ \mathrm{n} \wedge \mathrm{mb} /$. This is a common error among Spanish speakers since there is an influence of spelling on pronunciation. As a result, unknown words tend to be pronounced as spelt (O’Connor, 2009).

Accordingly, some of the participants did not distinguish the phoneme /a:/ in castle, given that vowels have no length in Spanish (Coe, 1987). Oddly, two students pronounced /'kaz.səl/ instead of /'ka:.səl/. The number of mispronunciations decreased considerably in words like island, autumn and knee, which seemed to be recognised easily.

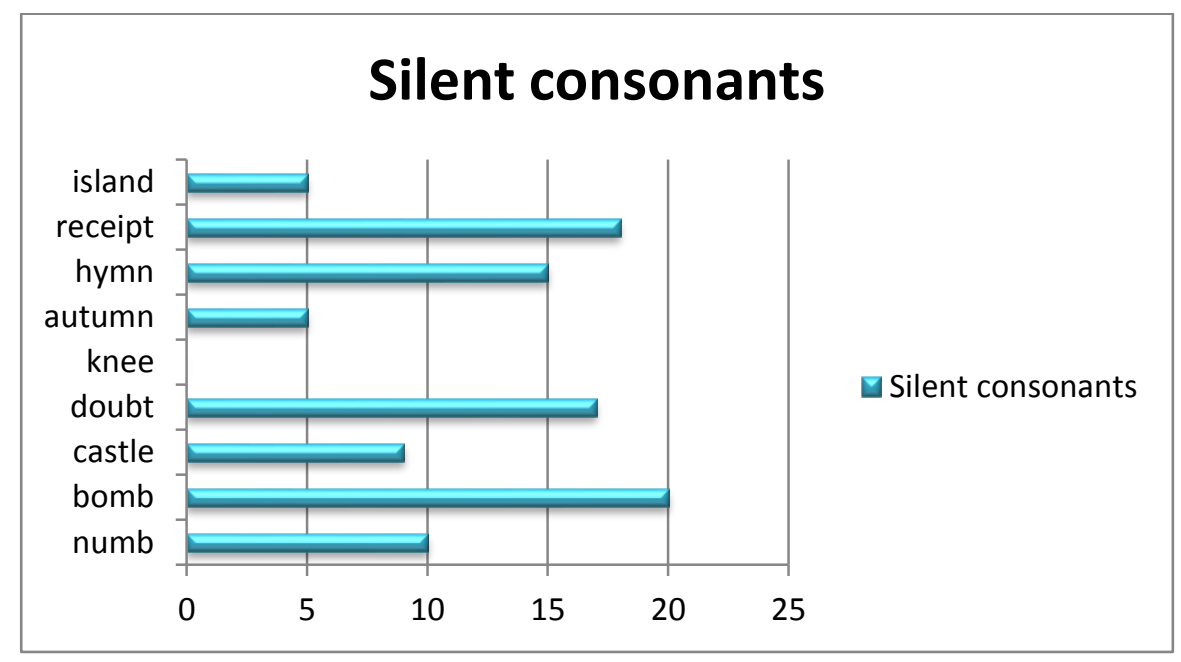

Figure 1. Silent consonants 
Figure 2 that follows shows similar trends. As for the word starving, approximately $34 \%$ of Medicine students pronounced the phoneme $/ \mathrm{v} /$ as $/ \mathrm{b} /$, considering that both of them sound exactly the same in their mother tongues, either Spanish or Catalan. Likewise, the phoneme $/ \mathrm{y} /$ does not appear at the end of a word in Spanish, so that starving is pronounced as /'sta:.ving/. Occasionally, enough and believe were pronounced as /e'n $\Lambda \mathrm{f} /$, /I'noug/, and /be'li:v/ respectively. Another mispronunciation that deserves special attention is that of rude, in which the $/ \mathrm{r} /$ is flapped (Coe, 1987).

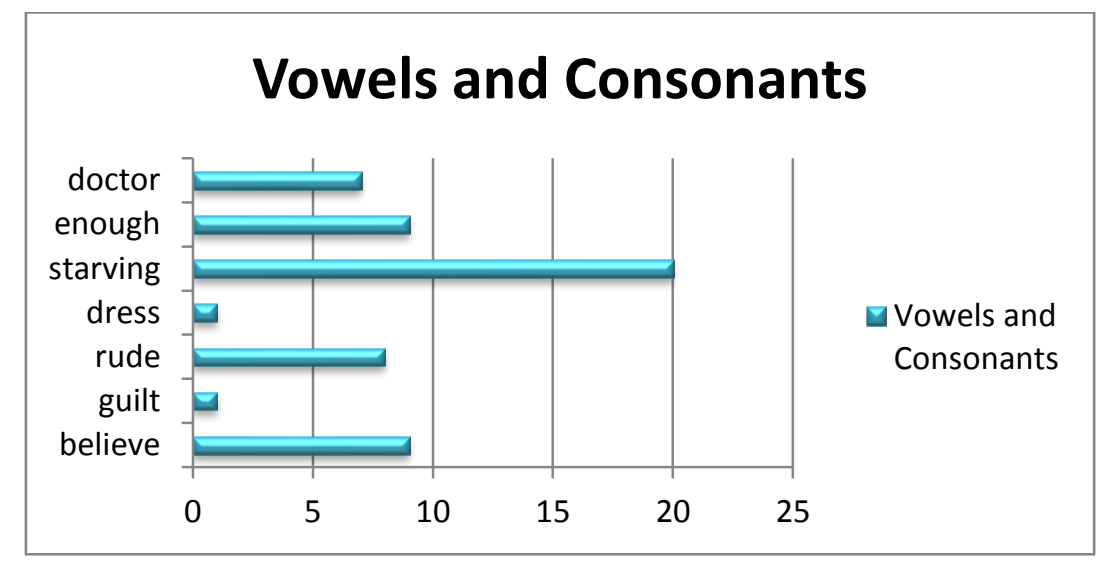

Figure 2. Vowels and Consonants

\subsection{Tongue Twister}

Results from the tongue twister activity suggest that most students could complete the activity satisfactorily. Nonetheless, at times participants had some problems in words like two, watched, and would. In this sense, 8 out of 63 learners forgot about the aspiration in / $t /$. Moreover, thirteen students failed to pronounce the -ed in watched, which was not articulated as in cooked /kokt/ but as in wanted /'wpn.tid/. As can be observed in Figure 3, the word would seemed to be the most challenging one. Actually, the silent /1/ was pronounced by fourteen participants. 


\section{Tongue twister}

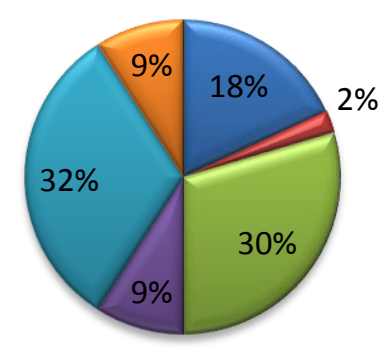

$\nabla$ two

$\nabla$ witches

$\square$ watched

$\square$ watches

$\square$ would

$\square$ watch

Figure 3. Tongue Twister

\section{Conclusion}

Technological tools such as Voki or LEO network, and more concretely the resource 'Learn English through dictation' have been explained and presented to university students in their English for Health Sciences module in order to improve and practise their English pronunciation.

As to the surveys explained above, it is worth to point out here that question 1 corresponding to the Final Survey, that is, I consider a waste of time learning with OERs. It slows down the learning process and should be optional (see Appendix), was given a 4 in a scale from 1 to 5 in 23 occasions from a total of 63 students. This figure is quite elevated or at least higher than we expected. The inclusion and use of OERs in a session within the English for Health Sciences module was expected to be largely accepted by the students. This result might be due to the raising issues in terms of social exclusion already mentioned. We realized that the students used different devices other than the regular PC. Some used tablets, others laptops, and not all them used the same operative system or browser, which caused some problems when using some of the resources proposed, as for example Voki, since it is in sync with Google and not with other web browsers such as Opera.

OERs are meant to engage students in the learning process of the target language and so occurred with the activities proposed for the session. OERs allowed students to work autonomously and at their own path. From the results obtained, we observed that the flexibility of OERs permitted students to record themselves a many times as needed and listen to the target sound easily, which enhanced their pronunciation improvement. Only 20 
out of 63 EFL learners showed some pronunciation problems in their final recorded production of words such as receipt and starving.

\section{References}

Bloom, B. S. (1956). Taxonomy of Educational Objectives. New York: David McKay.

Coe, N. (1987). Speakers of Spanish and Catalan. In Swan, M. \& Smith, B. (Eds.), Learner English: A teacher's guide to interference and other problems, (pp. 90-112). Cambridge: Cambridge University Press.

Conole, G. \& Alevizou, P. (2010). A literature review of the use of Web 2.0 tools in Higher Education. (HE Academy Commissioned report). Retrieved 10 January 2017 from http://www.headacademy.ac.uk/assets/evidence/Conole_Alevizou_2010.pdf

Domenech, J., Blazquez, D., de la Poza, E., \& Muñoz-Miquel, A. (2015). Exploring the impact of cumulative testing on academic performance of undergraduate students in Spain. Educational Assessment, Evaluation and Accountability, 27(2), 153-169.

LEONetwork. Learn English through dictation. Learnenglish.de [website]. Retrieved 17 January 2017 from http://www.learnenglish.de/dictationpage.html

Mayes, T. \& de Freitas, S. (2004). Stage 2: Review of e-learning theories, frameworks and models (JISC E-learning Models Desk Study). London: JISC.

O’Connor, J.D. (2009). Better English Pronunciation. (2nd ed.). Cambridge, UK: Cambridge University Press.

Shaeiwitz, J.A., \& Turton, R. (2003). Educating chemical engineers in product design. International Journal of Engineering Education, 19, 153-157.

Van Vugt, M., Hogan, R., \& Kaiser, R. B. (2008). Leadership, followership, and evolution: Some lessons from the past. American Psychologist, 63(3), 182-196.

Voki Home. (2017). Speaking Characters for Education. Retrieved 29 January 2017 from http://www.voki.com/

Wenk, B. (2010). Open educational resources (OER) inspire teaching and learning. In IEEE EDUCON, Education Engineering 2010 - The Future of Global Learning Engineering Education, 435-442. Madrid. 


\section{Appendix: Final Survey}

\section{Students' Questionnaire}

\begin{tabular}{|c|c|c|c|c|c|}
\hline & \multicolumn{5}{|c|}{ less-more } \\
\hline Questions & 1 & 2 & 3 & 4 & 5 \\
\hline $\begin{array}{l}\text { 1. I consider a waste of time learning with OERs. It } \\
\text { slows down the learning process and should be } \\
\text { optional. }\end{array}$ & & & & & \\
\hline $\begin{array}{l}\text { 2. The activities done using OERs are not attractive } \\
\text { and dynamic. }\end{array}$ & & & & & \\
\hline $\begin{array}{l}\text { 3. Using OERs to fulfil the activities has increased my } \\
\text { motivation to communicate in English. }\end{array}$ & & & & & \\
\hline $\begin{array}{l}\text { 4. I am able to manage my own language learning by } \\
\text { using OERs. }\end{array}$ & & & & & \\
\hline $\begin{array}{l}\text { 5. The implementation of OERs is aimed at developing } \\
\text { the competencies established in the course syllable. }\end{array}$ & & & & & \\
\hline $\begin{array}{l}\text { 6. The use of OERs has allowed me to improve my } \\
\text { English pronunciation. }\end{array}$ & & & & & \\
\hline 7. I will keep using OERs at home. & & & & & \\
\hline 8. I am satisfied with this teaching proposal. & & & & & \\
\hline
\end{tabular}

\section{Observations / Suggestions for improvement}

